удК 616.12-008.331.1-053.6

DOI 10.11603/1811-2471.2020.v.i3.11584

\title{
ВЗАЄМОЗВ'ЯЗОК ГІПЕРТРОФІї МІОКАРДА ЛІВОГО ШЛУНОЧКА ТА ДИСЛІПІДЕМІї У ДІТЕЙ ТА ПІДЛІТКІВ 3 АРТЕРІАЛЬНОЮ ГІПЕРТЕНЗІЄЮ
}

\author{
๑Т. А. Гайдук, Л. Р. Шостакович-Корецька, О. І. Гайдук \\ ДЗ «Дніпропетровська медична академія МОЗ України»
}

PЕзЮмЕ. Гіпертрофія лівого шлуночка (ГЛШ) є важливим клінічним станом, що істотно впливає на розвиток серйозних кардіоваскулярних подій і модифікується як гемодинамічними, так і негемодинамічними чинниками. Проведені епідеміологічні дослідження переконливо довели наявність зв'язку між порушеннями ліпідного обміну і розвитком серцево-судинних захворювань. У зв'язку з цим раннє виявлення ГлШ у дітей та підлітків і визначення чинників, що впливають на її розвиток, є важливим для профілактики серцево-судинних захворювань у дорослому віці.

Мета - визначити взаємозв'язок між змінами в ліпідному профілі сироватки крові у дітей та підлітків з артеріальною гіпертензією (АГ) та ГЛШ.

Матеріал і методи. Обстежено 118 підлітків з різними формами АГ - стабільною, лабільною формами і прегіпертензією у віці 12-17 років, госпіталізованих у дитяче міське кардіопульмонологічне відділення в зв'язку з підвищенням артеріального тиску при його разовому вимірюванні на амбулаторному етапі.

Результати. Встановлено високу частоту гіпертрофії міокарда лівого шлуночка у дітей і підлітків з артеріальною гіпертензією (33,9\%). Виділено дві групи підлітків з АГ із урахуванням наявності або відсутності ГлШ. Виявлено взаємозв'язок між наявністю дисліпідемії і гіпертрофією міокарда лівого шлуночка.

Висновки. Наявність дисліпідемії у дітей з АГ збільшує ризик розвитку ГлШ в 2-4 рази, причому найбільший вплив має підвищення рівнів тригліцеридів і ліпопротеїдів дуже низької щільності, зниження рівня холестерину високої щільності в сироватці крові. У дітей та підлітків з АГ та прегіпертензією необхідно визначати ліпідний профіль сироватки крові.

КлЮчОВІ СлОВА: артеріальна гіпертензія; дисліпідемія; гіпертрофія лівого шлуночка; діти; підлітки.

Вступ. Гіпертрофія лівого шлуночка (ГЛШ) $\epsilon$ важливим клінічним станом, що робить істотний внесок до розвитку серйозних кардіоваскулярних подій і модифікується як гемодинамічними, так i негемодинамічними чинниками $[1,3,4,6,7]$. Проведені епідеміологічні дослідження переконливо довели наявність зв'язку між порушеннями ліпідного обміну і розвитком серцево-судинних захворювань $[6,8]$. У зв'язку з цим раннє виявлення ГлШ у дітей та підлітків і визначення чинників, що впливають на їі розвиток, є важливим для профілактики серцево-судинних захворювань у дорослому віці.

Мета - визначити взаємозв'язок між змінами в ліпідному профілі сироватки крові у дітей та підлітків з артеріальною гіпертензією (АГ) та ГЛШ.

Матеріал і методи досліджень. Проведено комплексне обстеження 118 дітей та підлітків 3 АГ (60 дітей зі стабільною АГ, 40 дітей з лабільною АГ та 18 дітей з прегіпертензією). Контрольну групу склали 13 дітей з нормотензією.

Усім дітям з метою встановлення діагнозу АГ і визначення ії клініко-патогенетичних форм було проведено добове моніторування артеріального тиску за допомогою реєстратора Cardiotens-01 фірми «MEDITECH» (Угорщина) з плечовою манжеткою відповідно до віку дитини.

Стабільну АГ було діагностовано при рівні середньодобового АТ вище 95 перцентиля, індексі часу гіпертензії більше 50 \%, лабільна АГ визна- чалася при індексі часу гіпертензії від 25 \% до $50 \%$, однак середньодобовий АТ був нижчим за 95 перцентиль [5]. Прегіпертензія була визначена при рівні середньодобового АТ від 90 до 95 процентиля [2].

Для визначення наявності ураження органівмішеней (ГЛШ) у дітей з АГ проводили доплерехокардіографію за допомогою апарату «Megas» (Італія) за загальноприйнятою методикою [5]. Індекс маси міокарда лівого шлуночка (ІММЛШ) розраховували як відношення маси міокарда лівого шлуночка до зросту в ступені 2,7. У педіатричній практиці критерієм гіпертрофії лівого шлуночка $\epsilon$

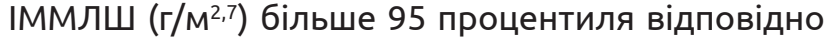
до статі.

Значення параметрів ліпідного спектра (загального холестерину (3ХC), холестерину ліпопротеїдів низької щільності (ХС ЛПНЩ), холестерину ліпопротеїдів дуже низької щільності (XC лПДНЩ), холестерину ліпопротеїдів високої щільності (ХС ЛПВЩ) та тригліцеридів (ТГ) сироватки венозної крові, узятої після 12-годинного голодування, визначали біохімічним методом. Оцінювали співвідношення фракцій ліпідів: 3ХC/ ЛПВЩ, ЛПНЩ/ЛПВЩ, ТГ/ЛПВЩ і показник різниці ЗХС і ЛПВЩ, що відображають міру ризику розвитку кардіоваскулярних захворювань у дорослих.

Статистичну обробку матеріалів дослідження проводили з використанням методів біостатисти- 
Огляди літератури, оригінальні дослідження, погляд на проблему, випадок з практики, короткі повідомлення ки, реалізованих у пакетах програм EXCEL-2003, STATISTICA 6.0 (Statsoft Inc., США). Для оцінки достовірності відмінностей за кількісною ознакою застосовували критерії Стьюдента та Манна-Уїтні, за якісною ознакою - критерій згоди хі-квадрат $\left(\chi^{2}\right)$ і точний критерій Фішера. Для оцінки сполученості розраховували коефіцієнт рангової кореляції Спірмена (г) і показник відношення шансів (ВШ).

Результати й обговорення. Встановлено, що частота ГлШ у дітей з АГ (стабільною і лабільною формами) та прегіпертензією склала 33,9 \% $(n=40)$ і була достовірно вищою $(P<0,05)$, порівня-

но з групою дітей з нормотензією (7,7 \%, n=1). Виділено дві групи підлітків з АГ із урахуванням наявності чи відсутності ГЛш.

При аналізі змін у ліпідному спектрі сироватки крові у дітей з АГ залежно від наявності ГлШ було відмічено (табл. 2), що середній рівень ЗХС знаходився в межах нормальних значень і склав у групі дітей без ГЛШ $(4,22 \pm 0,11)$ ммоль/л, в групі дітей з ГЛШ - $(4,23 \pm 0,15)$ ммоль/л $(P>0,70)$. При підвищенні рівня загального холестерину (більше 5,2 ммоль/л), глш відмічалася у 33,3 \% дітей ( $n=7$ з 21) і у 34,0 \% (n=33 з 97) дітей з нормальним рівнем 3XС ( $P>0,50)$ (табл. 1).

Таблиця 1. Частота гіпертрофії лівого шлуночка залежно від наявності дисліпідемії у дітей з артеріальною гіпертензією

\begin{tabular}{|c|c|c|c|c|c|c|c|c|c|c|c|c|c|c|c|c|}
\hline \multirow{3}{*}{$\begin{array}{c}\text { Озна- } \\
\text { ка }\end{array}$} & \multicolumn{16}{|c|}{ 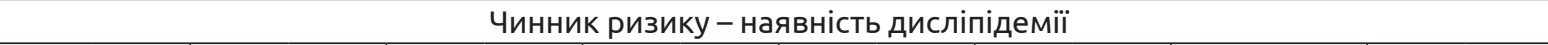 } \\
\hline & \multicolumn{2}{|c|}{$\begin{array}{c}\text { підвищен- } \\
\text { ня ЗХC }\end{array}$} & \multicolumn{2}{|c|}{$\begin{array}{c}\text { підвищен- } \\
\text { ня ТГ }\end{array}$} & \multicolumn{2}{|c|}{$\begin{array}{l}\text { підвищен- } \\
\text { ня лПДнщ }\end{array}$} & \multicolumn{2}{|c|}{$\begin{array}{c}\text { підвищен- } \\
\text { ня Лпнщщ }\end{array}$} & \multicolumn{2}{|c|}{$\begin{array}{c}\text { підви- } \\
\text { щення } \\
\text { беталіпо- } \\
\text { протеїдів }\end{array}$} & \multicolumn{2}{|c|}{$\begin{array}{c}\text { зниження } \\
\text { лпВщ }\end{array}$} & \multicolumn{2}{|c|}{$\begin{array}{c}\text { дисліпіде- } \\
\text { мія }\end{array}$} & \multicolumn{2}{|c|}{\begin{tabular}{|c} 
підвищен- - \\
ня $3 Х С /$ \\
лпВщ біль- \\
ше 4
\end{tabular}} \\
\hline & 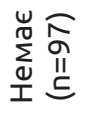 & 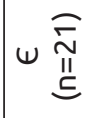 & 令 & 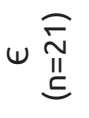 & $\sum_{\substack{0 \\
I}} \stackrel{0}{\underline{I I}}$ & $\omega \stackrel{\text { In }}{\stackrel{\text { II }}{\subseteq}}$ & 命 & 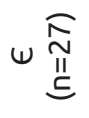 & 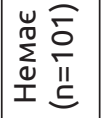 & $\omega \stackrel{\text { II }}{\stackrel{\text { II }}{E}}$ & 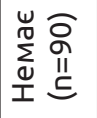 & $\omega \stackrel{\stackrel{0}{\mathbb{N}}}{\stackrel{\text { II }}{\subseteq}}$ & 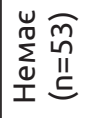 & $\omega \stackrel{\text { In }}{\stackrel{\text { II }}{\subseteq}}$ & 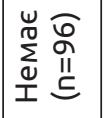 & $\omega \underset{\text { II }}{\approx}$ \\
\hline & \begin{tabular}{l}
$\widehat{a}$ \\
\multirow{0}{0}{0} \\
0 \\
0 \\
0
\end{tabular} & $+\frac{\widehat{0}}{\leftarrow}$ & 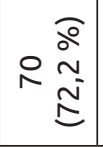 & $\infty \frac{\bar{o}}{\stackrel{\infty}{\infty}}$ & 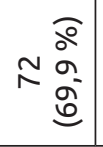 & 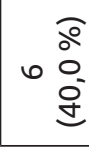 & 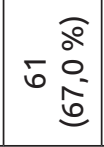 & $\begin{array}{rl} & \widehat{o} \\
\sim & 0 \\
0 & 0 \\
0\end{array}$ & 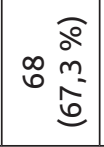 & $\begin{array}{l}\widehat{o} \\
\circ \\
\circ \\
\circ \\
\infty \\
\infty \\
n^{\infty}\end{array}$ & 농 & 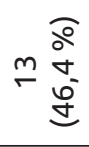 & 옹 & 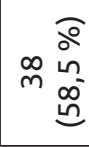 & $\begin{array}{rr}0 \\
0 \\
0 & 0 \\
0 & 0 \\
0 & 0\end{array}$ & $\mp$ \\
\hline & 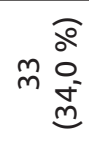 & 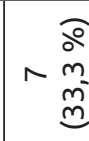 & $\begin{array}{r}\widehat{o} \\
\sim \\
\stackrel{\infty}{\infty} \\
\stackrel{\infty}{d}\end{array}$ & 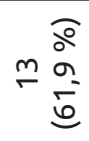 & 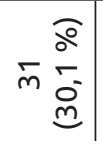 & $\begin{array}{r}10 \\
\circ \\
a \\
0 \\
0\end{array}$ & $\begin{array}{ll} & \widehat{a} \\
0 & 0 \\
m & 0 \\
m & 0\end{array}$ & 长 & 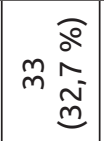 & 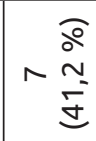 & 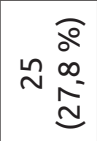 & 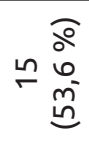 & 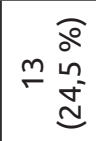 & 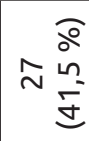 & 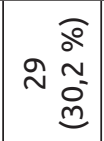 & $\mp$ \\
\hline & \multicolumn{2}{|c|}{$\varphi=0,01$} & \multicolumn{2}{|c|}{$\varphi=0,28$} & \multicolumn{2}{|c|}{$\varphi=0,21$} & \multicolumn{2}{|c|}{$\varphi=0,04$} & \multicolumn{2}{|c|}{$\varphi=0,06$} & \multicolumn{2}{|c|}{$\varphi=0,23$} & \multicolumn{2}{|c|}{$\varphi=0,1$} & \multicolumn{2}{|c|}{$\varphi=0,16$} \\
\hline ВШ & \multicolumn{2}{|c|}{$\begin{array}{c}\mathrm{BW}=0,97 \\
(0,36-2,64)\end{array}$} & \multicolumn{2}{|c|}{$\begin{array}{c}\mathrm{B} Ш=4,21 \\
(1,57-11,30)\end{array}$} & \multicolumn{2}{|c|}{$\begin{array}{c}\text { ВШ }=3,48 \\
(1,14-10,63)\end{array}$} & \multicolumn{2}{|c|}{$\begin{array}{c}\mathrm{BШ}=1,20 \\
(0,49-2,93)\end{array}$} & \multicolumn{2}{|c|}{$\begin{array}{c}\mathrm{BW}=1,44 \\
(0,50-4,13)\end{array}$} & \multicolumn{2}{|c|}{$\begin{array}{c}\mathrm{BШ}=3,00 \\
(1,25-7,19)\end{array}$} & \multicolumn{2}{|c|}{$\begin{array}{c}\mathrm{B} Ш=2,19 \\
(1,02-4,85) \\
\end{array}$} & \multicolumn{2}{|c|}{$\begin{array}{c}\mathrm{BШ}=2,31 \\
(0,90-5,93)\end{array}$} \\
\hline & \multicolumn{2}{|c|}{$\begin{aligned} \chi^{2} & =0,004 \\
P & =0,951\end{aligned}$} & \multicolumn{2}{|c|}{$\begin{array}{l}\chi^{2}=8,94 \\
P=0,003\end{array}$} & \multicolumn{2}{|c|}{$\begin{array}{l}\chi^{2}=5,22 \\
P=0,022\end{array}$} & \multicolumn{2}{|c|}{$\begin{array}{l}\chi^{2}=0,15 \\
P=0,695\end{array}$} & \multicolumn{2}{|c|}{$\begin{array}{l}\chi^{2}=0,47 \\
P=0,493\end{array}$} & \multicolumn{2}{|c|}{$\begin{array}{l}\chi^{2}=6,34 \\
P=0,012\end{array}$} & \multicolumn{2}{|c|}{$\begin{array}{l}\chi^{2}=3,83 \\
P=0,050\end{array}$} & \multicolumn{2}{|c|}{$\begin{array}{l}\chi^{2}=3,13 \\
P=0,077\end{array}$} \\
\hline 1 & \multicolumn{2}{|c|}{$P_{1}=0,583$} & \multicolumn{2}{|c|}{$P_{1}=0,004$} & $P_{1}=0$, &, 025 & $P_{1}=0$ & ,431 & $P_{1}=0$ & , 335 & $P_{1}=0$ & 012 & $P_{1}=0$ &, 040 & $P_{1}=0$ & 0,066 \\
\hline
\end{tabular}

Примітки: 1. \% розраховується до загальної кількості спостережень по даному чиннику ризику;

P - достовірність відмінностей за критерієм $\chi^{2} ; \mathrm{P}_{1}$ - достовірність відмінностей за точним критерієм Фішера.

Таблиця 2. Середні рівні показників ліпідного профілю крові у дітей з артеріальною гіпертензією залежно від

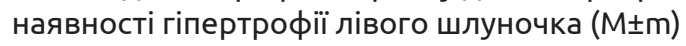

\begin{tabular}{|l|c|c|c|}
\hline \multicolumn{1}{c|}{$\begin{array}{c}\text { Показник, } \\
\text { ммоль/л }\end{array}$} & \multicolumn{2}{|c|}{ Групи } & Достовірність відмінностей \\
\cline { 2 - 3 } & мез Глш групами $(\mathrm{P})$
\end{tabular}


Огляди літератури, оригінальні дослідження, погляд на проблему, випадок з практики, короткі повідомлення

Середній рівень ТГ в сироватці крові також перебував у межах нормальних значень і склав $(0,98 \pm$ $0,05)$ ммоль/л у дітей без ГЛШ і $(1,25 \pm 0,11)$ ммоль/л у дітей з ГЛШ (табл. 2). При цьому рівень ТГ був достовірно вищим $(P=0,054)$ у дітей з АГ і гіпертрофією лівого шлуночка, ніж у дітей без ГЛШ (табл. 2).

Частота ГЛШ у дітей з гіпертригліцеридемією

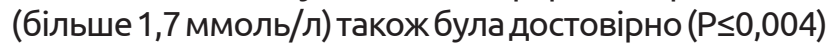
вищою і склала $61,9 \%$ (n=13) у порівнянні з дітьми, в яких підвищення рівня ТГ виявлено не було $(27,8 \%, \mathrm{n}=27)$ (табл. 1).

Середній рівень ЛПднЩ перебував у межах норми в усіх групах (табл. 2), але у дітей без ГлШ був істотно нижчим $(0,45 \pm 0,02$ ммоль/л), порівня-

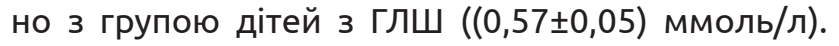
Відмінності між групами дітей без ГлШ і з їі наявністю за середніми рівнями ТГ і ЛПдНЩ достовірні з $\mathrm{P}=0,054$ і 0,057, відповідно.

При підвищеному рівні лПднщ (більше 0,78 ммоль/л) у дітей з артеріальною гіпертензією гіпертрофія лівого шлуночка спостерігалася у $60,0 \%$ випадків ( $n=9)$ і була достовірно $(P \leq 0,025)$ вищою, порівняно з групою дітей, в яких рівень лпднщ був у межах нормальних значень (30,0 \%, n=6) (табл. 1).

Середній рівень лПнЩ у сироватці крові в групах дітей без ГлШ і з їі наявністю не перевищував нормальних значень, не мав достовірних відмінностей $(P>0,40)$ і склав $(2,37 \pm 0,10)$ і $(2,47 \pm$ $0,13)$ ммоль/л, відповідно (табл. 2).

Частота ГЛШ була практично однаковою у дітей з підвищеними рівнями лПнЩ (більше 3,3 ммоль/л) і з нормальними їх значеннями. Так, при підвищених рівнях лпнщ гіпертрофія лівого шлуночка відмічалася у $37,0 \%(n=10)$ дітей і у $33,0 \%(n=30)$ дітей із значеннями ЛПнЩ в межах норми $(P>0,40)$ (табл. 1).

При оцінці змін рівня ЛПВЩ у сироватці крові було виявлено, що середній рівень ЛПВщу групах дітей без ГлШ і з ГлШ перебував у межах нормальнихзначеньісклав $(1,41 \pm 0,04) \mathrm{i}(1,19 \pm 0,05)$ ммоль/л. Проте, хоча значення ЛПВЩ було нормальним в обох групах, у групі дітей без ГЛШ середній рівень ЛПВЩ виявився достовірно вищим $(P<0,001)$, порівняно з таким у дітей з ГлШ (табл. 2).

Гіпертрофія лівого шлуночка спостерігалася значно частіше $(P \leq 0,012)$ у дітей, в яких було виявлено один із маркерів атерогенної дисліпідемії, - наявність знижених рівнів лПвЩ (менше 1,03 ммоль/л у хлопчиків і 1,3 ммоль/л у дівчаток).
Так, при зниженні рівня ЛПвЩ ГлШ відмічалася у $53,6 \%$ (n=15) дітей, порівняно з 27,8 \% ( $n=25)$ дітей з нормальними рівнями ЛПВЩ (табл. 1).

Наявність дисліпідемії (підвищення рівнів ЗХС, ТГ, ЛПДНЩ, ЛПНЩ і зниження ЛПВЩ) достовірно впливала $(\varphi=0,18 ; P \leq 0,050)$ на частоту виникнення ГЛШ у дітей з АГ. Частота ГЛШ за наявності дисліпідемії була достовірно вищою і склала $41,5 \%(n=27)$, порівняно з 24,5\% ( $n=13)$ за відсутності даного чинника ризику (табл. 1).

Більш виражені відмінності між групами дітей без ГлШ і з ГЛШ виявлено при аналізі співвідношень 3 ХС/ЛпвЩ $(P<0,01)$, ЛПНЩ/ЛПВЩ $(P<0,05)$ i ТГ/ЛПВЩ ( $>00,01)$ (табл. 2), середні рівні яких були достовірно нижчими в групі дітей без ГЛШ. Показник різниці рівнів 3 ХС і ЛПВЩ у порівнюваних групах достовірно не відрізнявся $(P>0,10)$.

При аналізі показників відносного ризику розвитку ГЛШ у дітей залежно від наявності змін у ліпідному профілі крові встановлено, що підвищення рівнів ТГ, ЛПДНЩ, ЛПВЩ, а також показники співвідношення ліпідних фракцій - ЗХС/ЛПВЩ, збільшують ризик розвитку ГлШ у дітей з АГ. Підвищення рівнів $3 Х С$, лПНЩ і $\beta$-ліпопротеїдів, за даними результатів нашого дослідження, істотно не впливало на розвиток ГЛШ (табл. 1).

Так, наявність дисліпідемії у дітей з АГ збільшує ризик розвитку ГлШ у 2,19 раза (ВШ=2,19; $\varphi=0,18 ; P \leq 0,05)$, підвищення рівнів ТГ - у 4,21 раза $(B Ш=4,21 ; \varphi=0,28 ; P \leq 0,004)$, ЛПДНЩ - у 3,48 раза (ВШ=3,48; $\varphi=0,21 ; P \leq 0,025)$, співвідношення ліпідних фракцій ЗХС/ЛПВЩ - у 2,31 раза (ВШ=2,31; $\varphi=0,16 ; P \leq 0,077)$. При зниженні рівня лПВЩ ризик розвитку ГЛШ збільшувався у 3,0 рази (ВШ=3,00; $\varphi=0,23 ; P \leq 0,012)$.

Висновки. Встановлено високу частоту гіпертрофії міокарда лівого шлуночка у дітей з артеріальною гіпертензією (33,9\%).

Наявність дисліпідемії у дітей та підлітків з АГ збільшує ризик розвитку ГЛШ у 2-4 рази, причому найбільше на збільшення відносного ризику формування ГЛШ впливає підвищення рівнів ТГ і ЛПДНЩ, зниження рівня ЛПВЩ у сироватці крові. Тому необхідно визначати ліпідний профіль сироватки крові у дітей та підлітків з АГ та прегіпертензією.

Перспективи подальших досліджень. Визначити стійкість артеріальної гіпертензії, змін у ліпідному профілі крові та гіпертрофії лівого шлуночка у підлітків та їх подальшу еволюцію до дорослого віку. 
Огляди літератури, оригінальні дослідження, погляд на проблему, випадок з практики, короткі повідомлення ЛІТЕРАТУРА

1. Метаболічні та гемодинамічні особливості артеріальної гіпертензії у підлітків залежно від маси тіла / М. М. КоренєВ, Л. Ф. Богмат, В. В. Никонова [та ін.] // Артериальная гипертензия. - 2015. - № 1 (39). - С. 36-44.

2. Марушко Ю. В. Аналіз і перспективи нових клінічних рекомендацій ААР (2017) скринінгу і контролю високого артеріального тиску у дітей та підлітків / Ю. В. Марушко, Т. В. Гищак // Современная педиатрия. 2018. - № 4. - С. 27-39. - Режим доступу: http://nbuv. gov.ua/UJRN/Sped_2018_4_6.

3. Гайдук Т. А. Артеріальна гіпертензія та предиктори метаболічного синдрому у дітей / Т. А. Гайдук, Л. Р. Шостакович-Корецька // Медичні перспективи. 2009. - T. XIV, № 2. - С. 103-106.

4. Взаємозв'язок індексу маси міокарда лівого шлуночка з різними факторами ризику в підлітків з артеріальною гіпертензією / Т. А. Гайдук, Л. Р. Шостакович-Корецька, О. І. Гайдук [та ін.] // Медичні перспективи - 2017. - Т. XXII. № 2, Ч. 1. - С. 28-31.

5. Cardiovascular disease risk factors and left ventricular hypertrophy in girls and boys with CKD / R. L. Rueb- ner, D. Ng, M. Mitsnefes [et al.] // CJASN. - 2016. No. 11 (11). - P. 1962-1968. DOI: 10.2215/CJN.01270216.

6. Factors influencing left ventricular hypertrophy in children and adolescents with or without family history of premature myocardial infarction / S. M. Hosseini, R. Kelishadi, N. Lotfi [et al.] // Advanced Biomedical Research. 2014. - No. 3. - P. 60. DOI: 10.4103/2277-9175.125821.

7. Ambulatory systolic blood pressure and obesity are independently associated with left ventricular hypertrophic remodeling in children. Journal of cardiovascular magnetic resonance / L. Jing, C. D. Nevius, C. M. Friday [et al.] // Official Journal of the Society for Cardiovascular Magnetic Resonance. - 2017. - No. 19 (1). - P. 86. DOI: 10.1186/s12968-017-0401-3.

8. The role of blood pressure, body weight and fat distribution on left ventricular mass, diastolic function and cardiac geometry in children / F. Pieruzzi, L. Antolini, F. R. Salerno [et al.]. // Journal of Hypertension. - 2015. - No. 33 (6). P. 1182-1192. DOI: 10.1097/HJH.0000000000000552.

\section{REFERENCES}

1. Korenev, M.M., Bogniat, L.F., \& Nikonova, W. (2015). Metabolichni ta hemodynamichni osoblyvosti arterialnoi hipertenzii u pidlitkiv zalezhno vid masy tila [Metabolic and hemodynamic features of arterial hypertension in adolescents, depending on body weight]. Arterialnaya gipertenziya - Hypertension, 1 (39), 36-44 [in Ukrainian].

2. Marushko, Yu.V., \& Gyshhak T.V. (2018). Analiz i perspektyvy novykh klinichnykh rekomendatsii AAR (2017) skryninhu i kontroliu vysokoho arterialnoho tysku u ditei ta pidlitkiv [Analysis and prospects of new clinical recommendations of AAR (2017) on screening and control of high blood pressure in children and adolescents]. Sovremennaya pediatriya - Modern Pediatrics, 4, 27-39. Retrieved from: http://nbuv.gov.ua/UJRN/Sped_2018_4_6 [in Ukrainian].

3. Haiduk, T.A., \& Shostakovych-Koreczka, L.R. Arterialna hipertenziia ta predyktory metabolichnoho syndrome $\mathrm{u}$ ditei [Arterial hypertension and predictors of metabolic syndrome in children]. Medychni perspektyvy - Medical Prospects, XIV, 2, 103-106 [in Ukrainian].

4. Haiduk, T.A., Shostakovych-Koreczka, L.R., \& Haiduk, O.I. (2017). Vzaiemozviazok indeksu masy miokarda livoho shlunochka $z$ riznymy faktoramy ryzyku $v$ pidlitkiv z arterialnoiu hipertenziieiu [Relationship between left ventricular myocardial mass index and various risk factors in adolescents with arterial hypertension]. Medychni perspektyvy - Medical Prospects, XXII, 2.1, 28-31 [in Ukrainian].

5. Ruebner, R.L., Ng, D., \& Mitsnefes, M. (2016). Cardiovascular disease risk factors and left ventricular hypertrophy in girls and boys with CKD. CJASN, 11 (11) 19621968; DOI:10.2215/CJN.01270216.

6. Hosseini, S.M., Kelishadi, R., \& Lotfi, N. (2014). Factors influencing left ventricular hypertrophy in children and adolescents with or without family history of premature myocardial infarction. Advanced Biomedical Research, 3, 60. DOI:10.4103/2277-9175.125821.

7. Jing, L., Nevius, C.D., \& Friday, C.M. (2017). Ambulatory systolic blood pressure and obesity are independently associated with left ventricular hypertrophic remodeling in children. Journal of Cardiovascular Magnetic Resonance: Official Journal of the Society for Cardiovascular Magnetic Resonance, 19 (1), 86. DOI:10.1186/s12968-017-0401-3.

8. Pieruzzi, F., Antolini, L., Salerno, F. R., Giussani, M., Brambilla, P., Galbiati, S., Mastriani, S., Rebora, P., Stella, A., Valsecchi, M. G., \& Genovesi, S. (2015). The role of blood pressure, body weight and fat distribution on left ventricular mass, diastolic function and cardiac geometry in children. Journal of Hypertension, 33 (6), 1182-1192. DOI:10.1097/HJH.0000000000000552.

\section{ВЗАИМОСВЯЗЬ ГИПЕРТРОФИИ МИОКАРДА ЛЕВОГО ЖЕЛУДОЧКА И ДИСЛИПИДЕМИИ У ДЕТЕЙ И ПОДРОСТКОВ С АРТЕРИАЛЬНОЙ ГИПЕРТЕНЗИЕЙ}

\section{๑Т. А. Гайдук, Л. Р. Шостакович-Корецкая, О. И. Гайдук

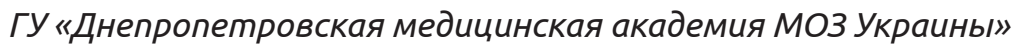

РЕЗЮМЕ. Гипертрофия левого желудочка (ГЛЖ) является важным клиническим состоянием, которое вносит существенный вклад в развитие серьезных кардиоваскулярных событий и модифицируется как гемодинамическими, так и негемодинамическими факторами. Проведенные эпидемиологические исследования убедительно 
Огляди літератури, оригінальні дослідження, погляд на проблему, випадок з практики, короткі повідомлення доказали наличие связи между нарушениями липидного обмена и развитием сердечно-сосудистых заболеваний. В связи с этим раннее выявление ГлЖ у детей и подростков и определение факторов, влияющих на ее развитие, является важным для профилактики сердечно-сосудистых заболеваний во взрослом возрасте.

Цель - определить взаимосвязь между изменениями в липидном профиле сыворотки крови у детей и подростков с артериальной гипертензией и гипертрофией левого желудочка.

Материал и методы. Обследовано 118 подростков с различными формами артериальной гипертензии (АГ) - стабильной, лабильной формами и прегипертензией в возрасте 12-17 лет, госпитализированных в детское городское кардиопульмонологическое отделение в связи с повышением артериального давления при его разовом измерении на амбулаторном этапе.

Результаты. Установлена высокая частота гипертрофии миокарда левого желудочка у детей и подростков с артериальной гипертензией (33,9%). Выделено две группы подростков с АГ с учетом наличия или отсутствия глж. Выявлена взаимосвязь между наличием дислипидемии и гипертрофией миокарда левого желудочка. Наличие дислипидемии у детей с АГ увеличивает риск развития ГЛЖ в 2-4 раза, причем наибольшее влияние оказывают повышение уровней триглицеридов и липопротеидов очень низкой плотности, снижение уровня липопротеидов высокой плотности в сыворотке крови. Необходимо определять липидный профиль сыворотки крови у детей и подростков с АГ и прегипертензией.

КЛЮчЕВЫЕ СЛОВА: артериальная гипертензия; дислипидемия; гипертрофия левого желудочка; дети; подростки.

\title{
RELATIONSHIP BETWEEN LEFT VENTRICULAR MYOCARDIAL HYPERTROPHY AND DYSLIPIDEMIA IN CHILDREN AND ADOLESCENTS WITH ARTERIAL HYPERTENSION
}

\author{
@T. A. Haiduk, L. R. Shostakovych-Koretska, O. I. Haiduk \\ Dnipropetrovsk Medical Academy
}

SUMMARY. Left ventricular hypertrophy (LVH) is an important clinical condition that makes a significant contribution to the development of serious cardiovascular events and is modified by both hemodynamic and non-hemodynamic factors. Epidemiological studies have convincingly proven the existence of a link between lipid metabolism disorders and the development of cardiovascular diseases. In this regard, the early detection of LVH in children and adolescents and the determination of factors affecting its development is important for the prevention of cardiovascular disease in adulthood.

The aim - to determine the relationship between changes in the lipid profile of blood serum in children and adolescents with arterial hypertension $(\mathrm{AH})$ and left ventricular hypertrophy.

Material and Methods. 118 adolescents aged 12-17 years with stable and labile forms of arterial hypertension and prehypertension hospitalized to cardiopulmonary department due to ambulatory single-measured blood pressure elevation were observed.

Results. The high frequency of left ventricular hypertrophy in children and adolescents with hypertension (33.9 \%) was established. Two groups of adolescents with hypertension were selected taking into account the presence or absence of LVH. The relationship between the presence of dyslipidemia and left ventricular myocardial hypertrophy was revealed. The presence of dyslipidemia in children with hypertension increases the risk of LVH by 2-4 times, with an increase in the levels of triglycerides and very low density lipoproteins, and a decrease in the level of high density lipoproteins in the blood serum. It is necessary to determine the lipid profile of blood serum in children and adolescents with hypertension and prehypertension.

KEY WORDS: arterial hypertension; left ventricular hypertrophy; dyslipidemia; children; adolescent.

Отримано 12.08.2020 